\title{
Seabird guano as a determinant of rocky intertidal community structure
}

\author{
A. L. Bosman \& P. A. R. Hockey \\ FitzPatrick Institute, University of Cape Town, Rondebosch 7700, South Africa
}

\begin{abstract}
Seabird guano is recognized as a powerful fertilizer and its entry into the intertidal zone of seabird breeding islands off the west coast of South Africa is hypothesized to cause enhanced intertidal algal production. Intertidal nutrient levels and algal production were measured monthly on the shores of seabird islands and on nearby mainland shores where no aggregations of seabirds occur. The shores of seabird islands were characterized by significantly higher levels of nutrients and significantly enhanced algal production. Nutrient enrichment, in conjunction with the predatory activity of African black oystercatchers on intertidal herbivorous limpets, leads to the formation of extensive, permanent mats of foliose algae on the shores of seabird breeding islands. Mussel spat, polychaetes and small crustaceans settle in the algal mats and provide food for small shorebirds. The structures of intertidal algal, invertebrate and avian communities on the shores of seabird islands are significantly altered by the activities of guano-producing seabirds and predatory shorebirds.
\end{abstract}

\section{INTRODUCTION}

Ecologists, in their quest to identify and understand the factors determining community structure in the rocky intertidal habitat, have, at various times, invoked the rigorous physical environment, inter- and intra-specific competition, and predator effects (Connell 1961, 1972, Lewis 1964, Stephenson \& Stephenson 1972, Paine 1974, Menge 1976, Estes et al. 1978). Recently, the role of birds in this regard has received much attention, since certain avian predators have been shown to influence attributes of intertidal communities, such as distribution patterns, abundance, and size of the component invertebrate species (Castilla 1981, Edwards et al. 1982, Hockey \& Branch 1983, Mercurio et al. 1985). In particular, oystercatchers (Charadriiformes, Haematopodidae), large shorebirds distributed around many of the world's coasts, have been shown to influence the structure of intertidal invertebrate communities (Giesel 1970, Hartwick 1981, Frank 1982).

Hockey \& Branch (1984) suggest that on 3 islands in Saldanha Bay (southwestern coast of South Africa) heavy predation by dense populations of African black oystercatchers Haematopus moquini Bonaparte on the dominant limpet Patella granularis Linnaeus results in a decrease in limpet numbers and consequently in a reduction in herbivory on algal sporelings. Extensive permanent mats of intertidal algae form on the shores of these islands: on nearby mainland shores where oystercatchers are much less common (Hockey 1983) and limpets numerous, such algal mats are entirely absent. In addition to the large numbers of oystercatchers, there are permanent colonies of seabirds on the offshore islands in Saldanha Bay. Cape gannets Sula capensis (Lichtenstein), jackass penguins Spheniscus demersus (Linnaeus) and Cape cormorants Phalacrocorax capensis (Sparrman) together number more than 200000 on the 3 major islands (Malgas, Jutten and Marcus Islands - Cooper et al. 1982, Crawford et al. 1983, Shelton et al. 1984). On Malgas Island the accumulation rate of seabird guano is sufficient to warrant annual commercial collection.

The excrement of colonially-nesting seabirds has long been recognized as a valuable fertilizer (Voelcker 1877. Watson 1930, Speigt 1940), and has been shown to enhance the nutrient status of marine and estuarine waters (Golovkin 1967, Ganning \& Wulff 1969, Golovkin \& Garkavaya 1975, Bédard et al. 1980). Terrestrial plants which are manured by seabird guano exhibit enhanced vitality, cover and production (Gillham 1977, Smith 1978), and research in the Barents Sea $\left(74^{\circ} 00^{\prime} \mathrm{N}, 36^{\circ} 00^{\prime} \mathrm{E}\right)$ indicates that enrichment of nearshore waters by seabird guano deposited in the sea is 
associated with enhanced phytoplankton production (Golovkin 1967, Zelickman \& Golovkin 1972, Golovkin \& Garkavaya 1975). Hansen (1981) has shown that peak intertidal algal standing crops on Año Nuevo Island $\left(37^{\circ} 07^{\prime} \mathrm{N}, 122^{\circ} 19^{\prime} \mathrm{W}\right)$ are associated with unusually high levels of $\mathrm{NH}_{4}-\mathrm{N}$ in the waters surrounding the island. Numerous seals haul out on the island shores and their excreta are washed from the island by waves. Peak $\mathrm{NH}_{4}-\mathrm{N}$ levels in nearshore waters correspond with peak numbers of seals utilizing the island.

The influence of seabird guano on intertidal algal production in the field has not been investigated. However, Bosman et al. (in press) showed experimentally that a rocky shore artificially enriched with seabird guano had significantly higher intertidal algal production than an adjacent unenriched shore. Should it be found that enhanced intertidal algal production in the field is associated with guano-derived nutrient enrichment of intertidal and nearshore waters, then the seabirds would be determinants of intertidal algal community structure at those sites. They may also modify invertebrate and avian community structure, since the macro-algal beds present on island shores form a settlement substratum for mussels and gastropods, crustaceans and polychaete worms which provide an important food source for small shorebirds that visit the island shores (Hockey \& Branch 1984). The algal beds and their associated invertebrate and vertebrate communities are absent from unenriched mainland shores (op. cit.).

This study aims to assess the extent to which seabirds influence intertidal community structure, in the light of research already conducted on the predatory effects of oystercatchers in the same system. Growth rates of intertidal algae, extent of algal cover, nutrient levels, and limpet densities at sites enriched and unenriched by seabird guano are compared.

\section{METHODS}

Study sites. Seven intertidal study sites in the Saldanha Bay area (Fig. 1) were visited monthly between December 1982 and April 1984. Two sites were on the shores of seabird breeding islands (Malgas and Jutten Islands; Fig. 1), and a third was on the shore of Marcus Island, a seabird breeding island which is joined to the mainland by means of a causeway, constructed in 1976 as part of harbour development (Fig. 1). A further 2 sites were on mainland shores outside the Bay where no aggregations of seabirds occurred (Mauritz Bay and Cape Columbine), and 2 more were on mainland shores within the Bay (North Bay and Bomgat). These last 2 sites, although having no regular aggregations of

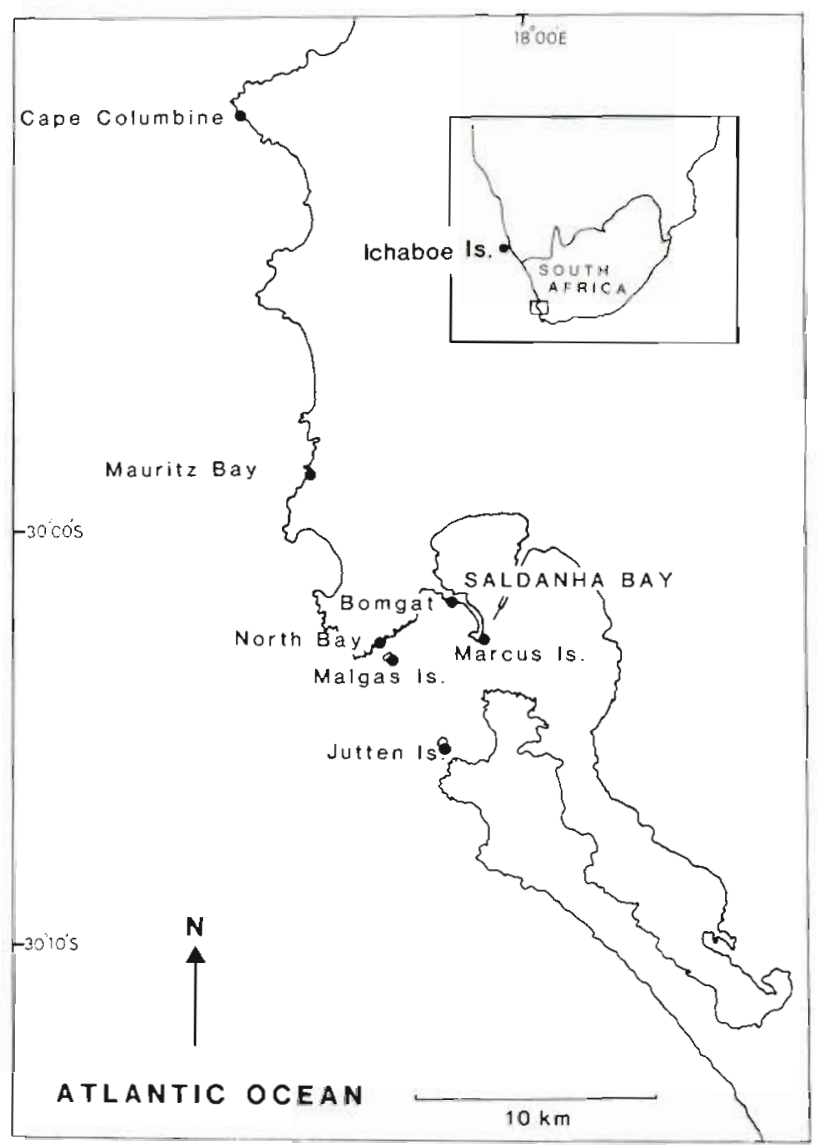

Fig. 1. Map of the Saldanha Bay area showing the positions of the 7 intertidal study sites

seabirds, were considered to be within the possible zone of influence of guano run off from the seabird breeding islands. Such sites might be expected to show features intermediate between the 'nutrient-rich' island sites and the unenriched mainland sites. North Bay and Bomgat are referred to as 'intermediate' sites, whereas Cape Columbine and Mauritz Bay are 'mainland sites. A site at Ichaboe Island $\left(26^{\circ} 17^{\prime} \mathrm{S}, 14^{\circ} 56^{\prime} \mathrm{E}_{i}\right.$ Fig. 1), a seabird breeding island off the coast of Namibia (Rand 1963), was visited in March 1985. All sites are influenced by cool, upwelled water in the Benguela Current region along the western coast of southern Africa (Shannon \& Stander 1977). The prevailing wind in the Saldanha Bay area is SSW (Hockey 1982).

At all sites the shore was of gently sloping granite, frequently exposed to strong wave action. The intertidal zone was considered to extend from the upper limit of occurrence of macro-algae to the upper limit of the mussel bed (neap low water mark) (Stephenson \& Stephenson 1972), and at each site the zone was divided into a low-, mid- and high-shore region of equal horizontal width. The middle and upper inter- 
tidal communities were dominated by the herbivorous limpet Patella granularis and the algal species Porphyra capensis Kütz and Enteromorpha sp. Mussels Choromytilus meridionalis (Krauss), Aulacomya ater (Molina) and Mytilus galloprovincialis Linnaeus dominated the infratidal fringe at all sites except Cape Columbine. Other herbivorous invertebrate species present in the intertidal zone were Patella granatina Linnaeus in the low-shore region and Siphonaria capensis Quoy \& Gaimard which occurred in perennial rockpools at all shore levels (see Stephenson \& Stephenson 1972 for general shore descriptions).

Algal production. At each study site in the Saldanha Bay area, the percentage algal cover and the density of Patella granularis in intertidal transects of fixed area were assessed monthly over a period of $13 \mathrm{mo}$. One comparable intertidal transect was made at Ichaboe Island in March 1985. The fixed transect areas extended from the upper limit of macro-algal occurrence to the upper limit of the mussel bed (neap low water mark), and where necessary, were marked with paint to ensure exact replication. The mean monthly percentage algal cover and limpet density were calculated for each site in the Saldanha Bay area. In addition, monthly algal production was measured in the low-, mid- and high-shore regions at each site. Herbivore exclusion plots were established in each region by painting around $0.1 \mathrm{~m}^{2}$ rectangular areas with copper-based antifouling paint. Intertidal grazers such as Patella spp. are repelled by the chemical components in this paint. Each month, after the rock surface had been scraped and burned (with a blow-torch) to remove settled algae, 4 high-intensity polystyrene 'productivity' strips measuring $30 \times 50 \times 2 \mathrm{~mm}$ (McQuaid 1981) were glued to the rock inside each exclusion plot. A rapidly setting epoxy (Araldite) was found to be most durable; some strips used in experiments not described here remained glued to intertidal rocks for more than 12 mo.

The strips were removed after $1 \mathrm{mo}$, wrapped in aluminium foil to exclude light, and stored frozen. Chlorophyll-a extracted from the algae growing on each strip (Strickland \& Parsons 1972) was used as an index of algal production. The chlorophyll-a estimations were obtained using the colorimetric techniques of Jeffrey \& Humphrey (1975). Resultant values were corrected for the exact area of the strip and for the number of days that the strip had been in position, such that the final index of algal growth was expressed in $\mu \mathrm{g}$ chlorophyll-a cm $\mathrm{cm}^{-2} \mathrm{mo}^{-1}$. For each shore level only the chlorophyll-a value from the strip with the maximum algal growth (out of each monthly sample of 4 strips) was used in analysis, as this was considered the best indication of potential algal production at that shore level. Means of monthly maximum algal production rates on the shores of island, intermediate and mainland sites were compared statistically using KruskalWallis 1-way analyses of variance by ranks; the test statistic used is ' $\mathrm{H}$ ' and the significance levels from these tests are derived using approximations to the chisquared distribution with 1 (number of sites $=2$ ) or 2 (number of sites $=3$ ) degrees of freedom (Sokal \& Rohlf 1981). In addition, the monthly maximum production rates at different shore levels within sites were compared using Wilcoxon matched-pairs signed-ranks tests (test statistic is ' $T$ ') with significance levels derived from approximations to the normal distribution (2-tailed) (Sokal \& Rohlf 1981).

Nutrients. Simultaneously with the determination of algal production at the study sites in the Saldanha Bay area, the levels of nutrients in rockpools in the intertidal zone were determined. A low-, mid- and highshore rockpool was chosen at each site and these were sampled monthly, 2 water samples being taken from each pool during a spring low tide. The low-shore pools were chosen at the spring low water mark and the high-shore pools were at the upper limit of the occurrence of Patella granularis. Although the pools were not of a standard size, they were flushed during each tidal cycle. Samples were filtered using Whatman glass microfibre filters, and then wrapped in aluminium foil and stored frozen. Subsequently, the concentrations of nitrite- and nitrate-bound nitrogen $\left(\mathrm{NO}_{2}^{-}-\mathrm{N}, \mathrm{NO}_{3}^{-}-\mathrm{N}\right)$, ammonium-bound nitrogen $\left(\mathrm{NH}_{4}^{+}-\right.$ $\mathrm{N})$ and phosphate-bound phosphorus $\left(\mathrm{PO}_{4}^{3-}-\mathrm{P}\right)$ were determined using a Technicon autoanalyser. Only those samples collected after July 1983 were analysed for $\mathrm{NH}_{4}-\mathrm{N}$ levels. The data were discarded in instances where the nutrient levels from the 2 samples differed by more than $20 \%$ (6\% of instances).

Mean nutrient levels were compared statistically using Kruskal-Wallis and Wilcoxon tests: the relations between nutrient levels in the 3 shore regions within each site were examined, as were the relations between nutrient levels on 'island', 'intermediate' and 'mainland' shores. At each site intertidal nutrient concentrations at each shore level were cross correlated with algal production in the low-, mid-and high-shore levels at the same site.

During 1983 surface water samples were collected at 3 mo intervals from a series of sample stations across the mouth of Saldanha Bay and around Malgas Island (Fig. 2). Duplicate water samples collected at each station were filtered using glass microfibre filters, and were stored frozen before being analysed for $\mathrm{NO}_{2}-\mathrm{N}$, $\mathrm{NO}_{3}-\mathrm{N}, \mathrm{NH}_{4}-\mathrm{N}$ and $\mathrm{PO}_{4}-\mathrm{P}$ using an autoanalyser. The stations were divided into mainstream and island stations on the basis of detailed current flow patterns in the Bay (Huizinga 1982). The mainstream stations are those to which guano run-off from the islands is 


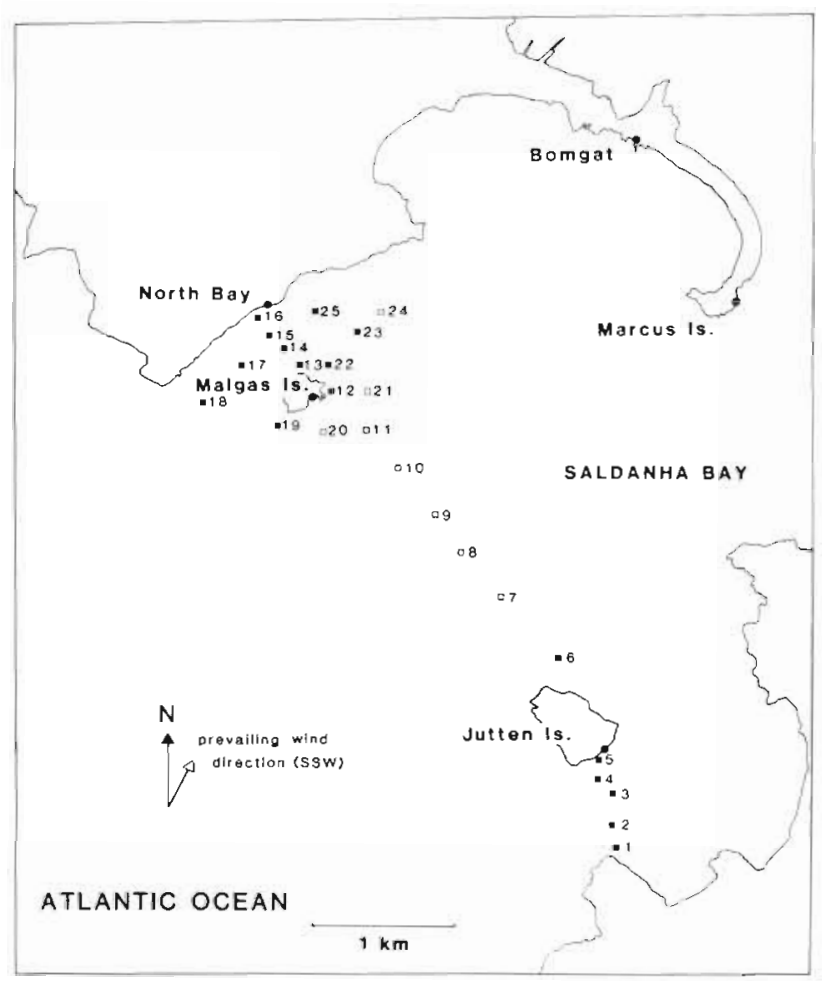

Fig. 2. Positions of island (a) and mainstream ( $\square$ ) sampling stations across the mouth of Saldanha Bay. ( $)$ : Study sites

unlikely to be transported under the influence of normal currents. The island stations lie in the path of currents deflected past islands under normal weather and wind conditions. Nutrient levels at mainstream and island stations were compared using KruskalWallis statistical tests.

The quantities of nutrients potentially available in fresh cormorant guano from intertidal rocks on Marcus Island, and in older, accumulated ('cap') gannet guano from Malgas Island, were determined. Solutions of cap guano in double-distilled water and in seawater were incubated at $10^{\circ} \mathrm{C}$ for $24 \mathrm{~h}$. Thereafter duplicate $2 \mathrm{ml}$ subsamples were removed and prepared for nutrient analysis in an autoanalyser. The effect of rain on the leaching of nutrients from fresh and cap guano was simulated in the laboratory using a spray gun with an adjustable nozzle. The spray gun was connected to a tap water supply with regulated water pressure, and artificial rain was sprayed onto an angled stage on which was positioned a sample of cap or fresh guano. Over a period of $30 \mathrm{~min}, 12 \mathrm{~mm}$ of 'rain' fell on the sample, and guano run-off was collected in a plastic beaker. Subsamples were prepared for nutrient analysis as described above.

The relation between monthly nutrient levels in rockpools at the study sites in Saldanha Bay and the amount of rain that fell at each site during the $5 \mathrm{~d}$ prior to sampling was investigated using correlation analy- sis. Rainfall measurements cited are those recorded at the nearby Cape Columbine weather station $\left(32^{\circ} 49^{\prime} \mathrm{S}\right.$, $17^{\circ} 51^{\prime} \mathrm{E}$ ) (monthly weather reports of the Weather Bureau, South African Transport Services).

\section{RESULTS}

\section{Algae and limpets}

Mean monthly algal cover was significantly higher on the shores of seabird breeding islands than on the mainland shores at Mauritz Bay and Cape Columbine (Kruskal-Wallis, $\mathrm{n}_{1}=26, \mathrm{n}_{2}=38, \mathrm{H}=45.6, \mathrm{P}<0.001$ ) (Fig. 3). Algal cover at the 2 intermediate sites was
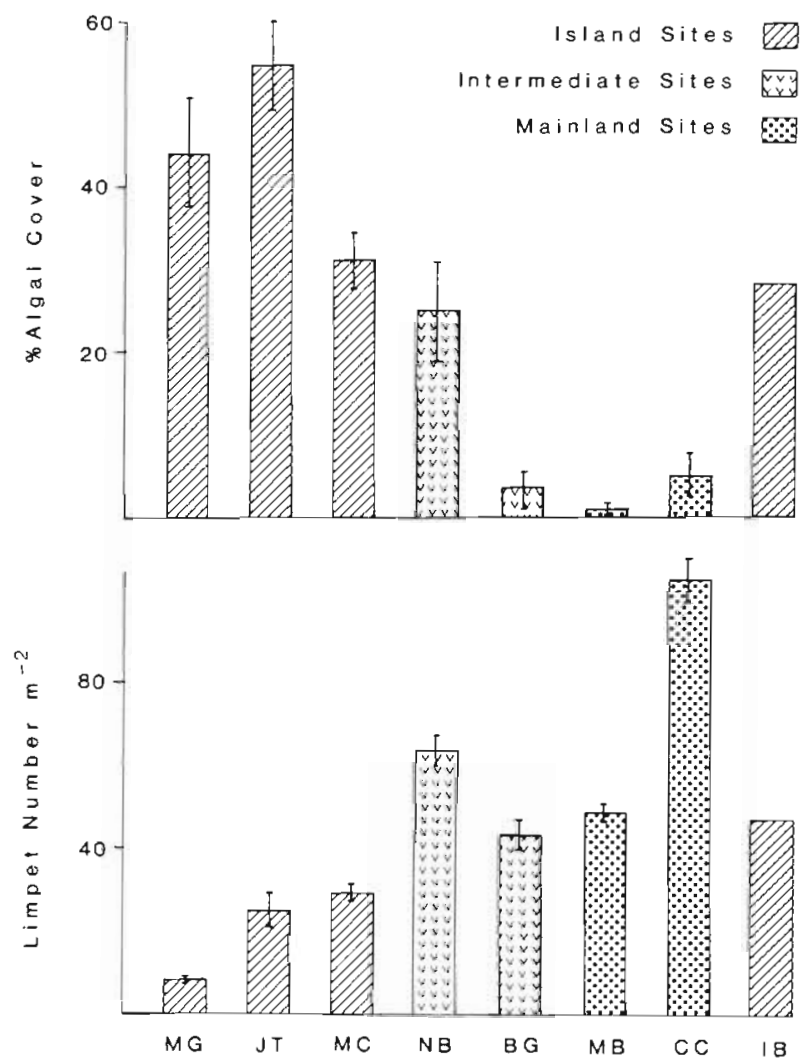

Fig. 3. Mean monthly percentage algal cover and mean monthly limpet density in fixed intertidal transects at Malgas (MG), Jutten (JT) and Marcus (MC) Islands, North Bay (NB), Bomgat (BG), Mauritz Bay (MB) and Cape Columbine (CC). Bars: standard deviation. Percentage algal cover and limpet density at the intertidal site on Ichaboe Island (IB) are presented

significantly different (Kruskal-Wallis, $\mathrm{n}_{1}=13, \mathrm{n}_{2}=$ $13, \mathrm{H}=14.4, \mathrm{P}<0.001$ ), the North Bay shores having a mean algal cover comparable with island shores, while algal cover at Bomgat fell within the range recorded at the mainland sites outside Saldanha Bay (Fig. 3). The differences between mean monthly limpet densities 
were equally clear: limpet densities were significantly lower on island shores than on mainland shores (Kruskal-Wallis, $\mathrm{n}_{1}=26, \mathrm{n}_{2}=38, \mathrm{H}=45.4, \mathrm{P}<0.001$ ) and mean limpet densities at 'intermediate' sites were more comparable with mainland than with island densities (Fig. 3). The shore at Ichaboe Island was characterized by fairly extensive algal cover (comparable with some Saldanha Bay island shores), and relatively high limpet density (comparable with some mainland shores), thus being most similar in intertidal algal and limpet community structure to the North Bay site (Fig. 3).

Mean monthly maximum algal production was significantly higher on island shores than on mainland shores, at all shore levels (Kruskal-Wallis, $\mathrm{n}_{1}=30$, $\mathrm{n}_{2}=45$; low-shore: $\mathrm{H}=12.3, \mathrm{P}<0.001$; mid-shore: $\mathrm{H}=10.6, \quad \mathrm{P}<0.01$; high-shore: $\mathrm{H}=9.2, \quad \mathrm{P}<0.01$ ) (Table 1). In addition, monthly maximum algal production generally was higher in the low-shore region than in the mid-shore region at the same site (Wilcoxon, $\mathrm{n}=102, \mathrm{~T}=305, \mathrm{P}<0.001$ ) and similarly mid-shore algal production was higher than high-shore production at the same site (Wilcoxon, $\mathrm{n}=99, \mathrm{~T}=319$, $\mathrm{P}<0.001$ ) (Table 1).

\section{Nutrients}

On island shores, where much seabird guano is deposited above the high-water mark, there was a tendency for mean nutrient levels to be higher in highshore rockpools than in low-shore pools, but none of the differences was statistically significant. At mainland sites there was a similar lack of significant differ- ence between high- and low-shore nutrient levels except for the levels of $\mathrm{NO}_{2}-\mathrm{N}$ and $\mathrm{NO}_{3}-\mathrm{N}$ which were significantly higher in low-shore pools than in highshore pools (Wilcoxon; $\mathrm{NO}_{2}-\mathrm{N}: \mathrm{n}=29, \mathrm{~T}=112.5$, $\mathrm{P}<0.05 ; \mathrm{NO}_{3}-\mathrm{N}: \mathrm{n}=19, \mathrm{~T}=19.0, \mathrm{P}<0.01$ ). In view of the comparability of nutrient levels in the 3 shore regions, monthly nutrient levels for the whole intertidal zone at each site were calculated using the mean of nutrient levels measured in the low-, mid- and highshore pools at each site. These monthly mean intertidal nutrient values are used in subsequent analyses and are shown for selected sites in Fig. 4 and 5 with the values for $\mathrm{NO}_{2}-\mathrm{N}, \mathrm{NO}_{3}-\mathrm{N}$ and $\mathrm{NH}_{4}-\mathrm{N}$ combined and expressed as total nitrogen.

Mean intertidal nutrient levels at Malgas, Jutten and Marcus Islands were not significantly different for any

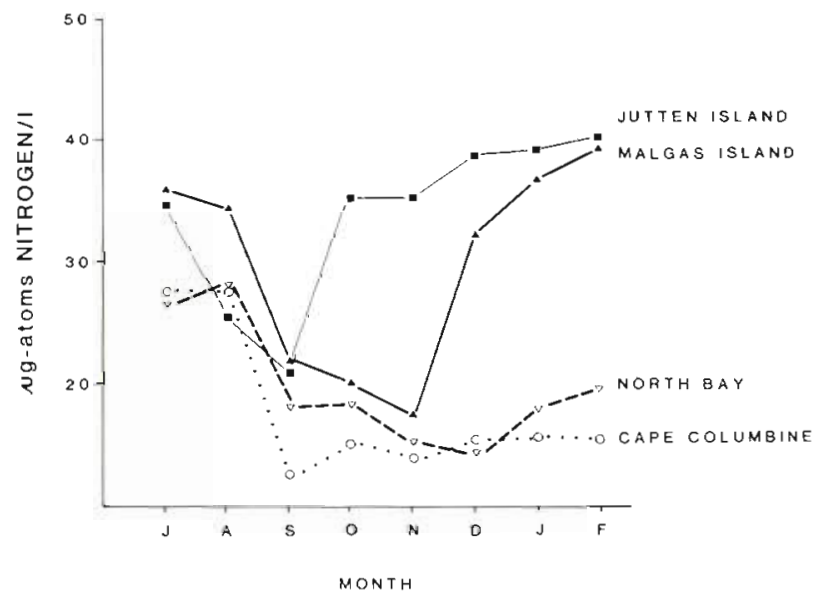

Fig. 4. Three mo running means of concentrations of nitrogen (in the form of $\mathrm{NO}_{2}-\mathrm{N}, \mathrm{NO}_{3}-\mathrm{N}$ and $\mathrm{NH}_{4}-\mathrm{N}$ ) recorded in intertidal rockpools at selected study sites in the Saldanha Bay area
Fig. 5. Three mo running means of $\mathrm{PO}_{4}-\mathrm{P}$ recorded in intertidal rockpools at selected study sites in the Saldanha Bay area

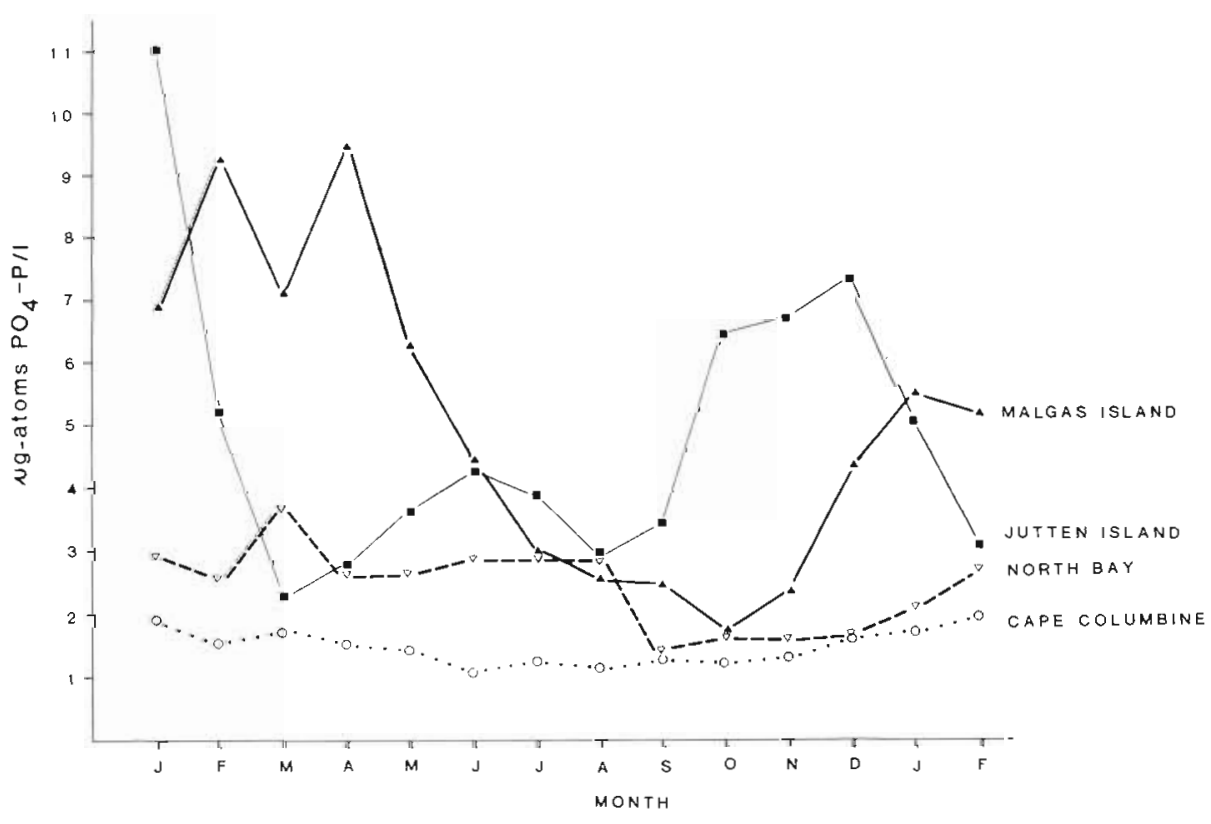


Table 1. Maximum monthly algal production ( $\mu \mathrm{g}$ chlorophyll a $\mathrm{cm}^{-2} \mathrm{mo}^{-1}$ ) on intertidal productivity strips at different shore levels at the study sites in Saldanha Bay

\begin{tabular}{|c|c|c|c|c|c|c|c|}
\hline Month & Malgas & Jutten & Marcus & $\begin{array}{c}\text { North } \\
\text { Bay }\end{array}$ & Bomgat & $\begin{array}{c}\text { Mauritz } \\
\text { Bay }\end{array}$ & $\begin{array}{c}\text { Cape } \\
\text { Columbine }\end{array}$ \\
\hline \multicolumn{8}{|l|}{ Low } \\
\hline Jan 83 & 0.01 & 4.57 & 20.92 & 0.02 & 0.01 & 14.19 & 0.00 \\
\hline \multicolumn{8}{|l|}{ Feb } \\
\hline Mar & 0.34 & 40.15 & 24.48 & 0.91 & 0.22 & 11.28 & 0.04 \\
\hline Apr & 23.97 & 107.13 & 52.55 & 2.41 & 18.04 & 4.97 & 0.42 \\
\hline May & 8.00 & 55.65 & 40.98 & 37.74 & 32.43 & 11.42 & 0.05 \\
\hline Jun & 21.47 & 56.61 & 19.82 & 6.86 & 4.33 & 8.85 & 3.37 \\
\hline Jul & 2.16 & 24.10 & 32.00 & 26.71 & 2.00 & 6.61 & 13.21 \\
\hline Aug & 0.35 & 40.53 & 38.62 & 24.46 & 0.53 & 3.46 & 0.13 \\
\hline Sep & 3.46 & 47.96 & 42.30 & 1.17 & 0.12 & 3.44 & 1.24 \\
\hline Oct & 7.70 & 18.59 & 8.39 & 16.68 & 5.15 & 4.58 & 3.22 \\
\hline Nov & 8.22 & 97.29 & 29.37 & 12.02 & 12.63 & 61.59 & 28.80 \\
\hline Dec & 25.38 & 23.32 & 15.51 & 117.35 & 137.42 & 22.85 & 0.32 \\
\hline Jan 84 & 0.44 & 20.72 & 2.53 & 8.25 & 7.18 & 43.60 & 0.71 \\
\hline Feb & 6.59 & 22.73 & 32.60 & 1.15 & 21.45 & 4.86 & 1.72 \\
\hline Mar & 1.50 & 21.59 & 20.63 & 2.31 & 22.43 & 9.29 & 0.51 \\
\hline Apr & 0.47 & 55.41 & 3.65 & 0.55 & 18.56 & 6.90 & 0.04 \\
\hline \multicolumn{8}{|l|}{ Mid } \\
\hline $\operatorname{Jan} 83$ & 0.02 & 0.03 & 1.29 & 0.00 & 0.01 & 0.01 & 0.00 \\
\hline \multicolumn{8}{|l|}{ Feb } \\
\hline $\begin{array}{l}\text { Mar } \\
\text { Apr }\end{array}$ & 0.17 & 0.80 & 4.18 & 0.55 & $\begin{array}{l}0.02 \\
1.17\end{array}$ & $\begin{array}{l}0.02 \\
0.60\end{array}$ & 0.01 \\
\hline $\begin{array}{l}\text { Apr } \\
\text { May }\end{array}$ & 0.32 & 38.10 & 2.92 & 0.93 & $\begin{array}{l}1.17 \\
0.13\end{array}$ & $\begin{array}{l}0.60 \\
0.68\end{array}$ & 0.01 \\
\hline $\begin{array}{l}\text { May } \\
\text { Jun }\end{array}$ & 0.26 & 10.60 & 31.04 & 1.36 & $\begin{array}{l}0.13 \\
0.06\end{array}$ & $\begin{array}{l}0.68 \\
9.73\end{array}$ & $\begin{array}{l}0.00 \\
0.03\end{array}$ \\
\hline $\begin{array}{l}\text { Jun } \\
\text { Jul }\end{array}$ & 2.03 & 23.17 & 23.58 & 1.79 & $\begin{array}{l}0.06 \\
0.03\end{array}$ & $\begin{array}{l}9.73 \\
7.30\end{array}$ & $\begin{array}{l}0.03 \\
3.08\end{array}$ \\
\hline $\begin{array}{l}\text { Jul } \\
\text { Aug }\end{array}$ & 7.16 & 28.07 & 18.44 & 4.88 & $\begin{array}{l}0.03 \\
0.04\end{array}$ & $\begin{array}{l}7.30 \\
9.96\end{array}$ & $\begin{array}{l}3.08 \\
0.02\end{array}$ \\
\hline $\begin{array}{l}\text { Aug } \\
\text { Sep }\end{array}$ & 0.19 & 2.27 & 0.31 & & $\begin{array}{l}0.04 \\
0.04\end{array}$ & $\begin{array}{l}9.96 \\
1.78\end{array}$ & $\begin{array}{l}0.02 \\
0.02\end{array}$ \\
\hline $\begin{array}{l}\text { Sep } \\
\text { Oct }\end{array}$ & 1.35 & 0.58 & 18.63 & $\begin{array}{l}0.02 \\
3.70\end{array}$ & $\begin{array}{l}0.04 \\
0.02\end{array}$ & $\begin{array}{l}1.78 \\
7.36\end{array}$ & $\begin{array}{l}0.02 \\
0.30\end{array}$ \\
\hline $\begin{array}{l}\text { Oct } \\
\text { Nov }\end{array}$ & 1.15 & 3.90 & 15.64 & $\begin{array}{l}3.70 \\
1.55\end{array}$ & $\begin{array}{l}0.02 \\
0.04\end{array}$ & $\begin{array}{r}7.36 \\
11.47\end{array}$ & $\begin{array}{l}0.30 \\
0.11\end{array}$ \\
\hline Dec & 0.33 & 14.67 & 1.31 & $\begin{array}{l}1.55 \\
1.06\end{array}$ & $\begin{array}{l}0.04 \\
0.09\end{array}$ & $\begin{array}{r}11.47 \\
0.54\end{array}$ & $\begin{array}{l}0.11 \\
0.02\end{array}$ \\
\hline Jan 84 & 0.38 & 6.38 & 0.54 & $\begin{array}{l}1.06 \\
1.45\end{array}$ & $\begin{array}{l}0.09 \\
0.06\end{array}$ & $\begin{array}{l}0.54 \\
1.01\end{array}$ & $\begin{array}{l}0.02 \\
0.03\end{array}$ \\
\hline Feb & 0.05 & 0.11 & $\begin{array}{l}0.28 \\
1.88\end{array}$ & & $\begin{array}{l}0.06 \\
0.05\end{array}$ & $\begin{array}{l}1.01 \\
0.94\end{array}$ & $\begin{array}{l}0.03 \\
0.02\end{array}$ \\
\hline Mar & 0.05 & $\begin{array}{l}0.22 \\
2.49\end{array}$ & $\begin{array}{l}1.88 \\
9.22\end{array}$ & $\begin{array}{l}0.58 \\
0.61\end{array}$ & $\begin{array}{l}0.05 \\
0.02\end{array}$ & $\begin{array}{l}0.94 \\
0.39\end{array}$ & $\begin{array}{l}0.02 \\
0.03\end{array}$ \\
\hline Apr & $\begin{array}{l}0.06 \\
0.15\end{array}$ & $\begin{array}{l}2.49 \\
1.39\end{array}$ & $\begin{array}{l}9.22 \\
0.32\end{array}$ & $\begin{array}{l}0.61 \\
0.83\end{array}$ & $\begin{array}{l}0.02 \\
0.04\end{array}$ & $\begin{array}{l}0.39 \\
0.17\end{array}$ & $\begin{array}{l}0.03 \\
0.02\end{array}$ \\
\hline \multirow{2}{*}{\multicolumn{4}{|c|}{ High }} & & & & 0.02 \\
\hline Jan 83 & 0.01 & 0.02 & 0.03 & 0.02 & 0.02 & 0.00 & \\
\hline \multicolumn{8}{|l|}{$\begin{array}{l}\text { Jan } 83 \\
\text { Feb }\end{array}$} \\
\hline Mar & 0.01 & 0.03 & 2.05 & 0.02 & 0.01 & 0.01 & 0.09 \\
\hline Apr & 0.04 & 0.12 & 0.56 & 0.01 & 0.12 & 0.05 & 0.03 \\
\hline May & 0.07 & 0.14 & 3.35 & 0.14 & 0.02 & 0.06 & 0.03 \\
\hline Jun & 0.02 & 0.36 & 6.86 & 5.69 & 0.03 & 0.02 & 0.02 \\
\hline Jul & 0.12 & 1.79 & 19.43 & 0.28 & 0.03 & 3.54 & 0.23 \\
\hline Aug & 0.03 & 0.04 & 0.15 & 0.19 & 0.02 & 0.16 & 0.08 \\
\hline Sep & 0.03 & 0.04 & 0.10 & 0.03 & 0.02 & 0.03 & 0.02 \\
\hline Oct & 0.05 & 0.10 & 0.55 & 0.33 & 0.01 & 0.04 & 0.02 \\
\hline Nov & 0.05 & 0.05 & 0.54 & 0.08 & 0.02 & 0.03 & 0.02 \\
\hline $\mathrm{Dec}$ & 0.13 & 0.02 & 0.13 & 0.13 & 0.03 & 0.06 & 0.02 \\
\hline $\operatorname{Jan} 84$ & 0.02 & 0.02 & 0.03 & 0.03 & 0.01 & 0.02 & 0.03 \\
\hline Feb & 0.04 & 0.02 & 0.28 & 0.03 & 0.01 & 0.03 & 0.02 \\
\hline Mar & 0.02 & 0.02 & 0.69 & 0.04 & 0.03 & 0.01 & 0.01 \\
\hline Apr & 0.02 & 0.02 & 0.59 & 0.14 & 0.02 & 0.01 & 0.01 \\
\hline
\end{tabular}

of the 4 nutrients considered (Kruskal-Wallis tests). Similarly the mean intertidal nutrient levels recorded at the 2 mainland sites (Cape Columbine and Mauritz Bay) were not significantly different, but the mean levels of $\mathrm{NO}_{2}-\mathrm{N}, \mathrm{NO}_{3}-\mathrm{N}$ and $\mathrm{PO}_{4}-\mathrm{P}$ were significantly higher at the North Bay site than at the Bomgat site (Kruskal-Wallis, $\mathrm{n}_{1}=16, \mathrm{n}_{2}=16 ; \mathrm{NO}_{2}-\mathrm{N}: \mathrm{H}=5.12$, $\mathrm{P}<0.05 ; \mathrm{NO}_{3}-\mathrm{N}: \mathrm{H}=6.96, \mathrm{P}<0.01 ; \mathrm{PO}_{4}-\mathrm{P}: \mathrm{H}=5.20$, $\mathrm{P}<0.05$ ). Consequently these intermediate' sites were excluded as a group from comparisons of mean nu- 
trient levels, but since they were both within the potential zone of influence of guano run-off from the seabird islands, and neither had permanent aggregations of seabirds, reasons for their differing nutrient levels will be discussed.

When combined data from island sites and combined data from mainland sites were compared, mean intertidal nutrient levels were always significantly higher on island shores than on mainland shores (KruskalWallis; $\mathrm{NO}_{2}-\mathrm{N}: \mathrm{n}_{1}=32, \mathrm{n}_{2}=48, \mathrm{H}=21.45$, $\mathrm{P}<0.0001 ; \quad \mathrm{NO}_{3}-\mathrm{N}: \mathrm{n}_{1}=31, \mathrm{n}_{2}=45, \mathrm{H}=12.13$, $\mathrm{P}<0.0001 ; \mathrm{NH}_{4}-\mathrm{N}: \mathrm{n}_{1}=20, \mathrm{n}_{2}=30, \mathrm{H}=10.55$, $\mathrm{P}<0.005 ; \quad \mathrm{PO}_{4}-\mathrm{P}: \quad \mathrm{n}_{1}=32, \mathrm{n}_{2}=47, \mathrm{H}=34.08$, $P<0.001$ ). Thus, the sites which have significantly elevated intertidal nutrient levels (viz. the shores of seabird breeding islands) are also the sites which show enhanced intertidal algal production, although within each site, algal production was not significantly correlated with the levels of a particular nutrient measured at any shore level. The North Bay site also showed a higher algal production rate (Table 1) and significantly elevated intertidal levels of $\mathrm{NO}_{2}-\mathrm{N}, \mathrm{NO}_{3}-\mathrm{N}$ and $\mathrm{PO}_{4}-\mathrm{P}$ when compared with the other 'intermediate' site, Bomgat. Seabirds were not present in permanent aggregations on the shores at either site.

Ammonium was the dominant inorganic nitrogen compound released from guano in solution and occurred, in solution, at 100 times the concentration of $\mathrm{NO}_{2}$ -

Table 2. Quantities of nutrients ( $\mu$ g-at $g^{1}$ dry guano) released from cap guano and from fresh guano after solution in double-distilled (DD) water and in seawater (SW) for $24 \mathrm{~h}$, and after treatment with $12 \mathrm{~mm}$ of artificial rain. Nutrients released after rain treatment are also expressed as a percentage of nutrients released after solution in double-distilled water for $24 \mathrm{~h}$

\begin{tabular}{|lrrrr|}
\hline Treatment & $\mathrm{NO}_{2}-\mathrm{N}$ & $\mathrm{NO}_{3}-\mathrm{N}$ & $\mathrm{NH}_{4}-\mathrm{N}$ & $\mathrm{PO}_{4}-\mathrm{P}$ \\
\hline Cap guano & & & & \\
24 h (SW) & 12.2 & 113.2 & 2490.8 & 160.7 \\
& \pm 3.7 & \pm 55.0 & \pm 740.6 & \pm 46.0 \\
$24 \mathrm{~h}$ (DD) & 10.0 & 98.7 & 2636.5 & 304.5 \\
& \pm 3.9 & \pm 62.3 & \pm 666.5 & \pm 38.5 \\
12 mm rain & 0.1 & 0.2 & 8.5 & 0.5 \\
& \pm 0.0 & \pm 0.0 & \pm 0.7 & \pm 0.1 \\
$\%$ & $1.0 \%$ & $0.2 \%$ & $0.3 \%$ & $0.2 \%$ \\
Fresh guano & 15.9 & 337.9 & 2126.4 & 137.1 \\
$24 \mathrm{~h}$ (SW) & \pm 5.2 & \pm 25.3 & \pm 356.9 & \pm 51.2 \\
& 12.0 & 83.9 & 1988.0 & 207.6 \\
$24 \mathrm{~h}$ (DD) & \pm 1.6 & \pm 15.6 & \pm 433.3 & \pm 92.7 \\
& 0.1 & 1.2 & 154.4 & 15.6 \\
12 mm rain & \pm 0.0 & \pm 0.1 & \pm 15.0 & \pm 0.4 \\
& $0.8 \%$ & $1.4 \%$ & $7.8 \%$ & $7.5 \%$ \\
\hline
\end{tabular}

$N$ (Table 2). Rain delivered by artificial apparatus $(12 \mathrm{~mm}$ of rain in $30 \mathrm{~min}$ ) to samples of cap guano and fresh guano resulted in the leaching of nutrients from the guano. However, less than $1 \%$ of the nutrients released from cap guano after solution in double-distilled water for $24 \mathrm{~h}$ were released by $12 \mathrm{~mm}$ of continuous artificial rain (Table 2). Up to $8 \%$ of nutrients potentially available in fresh guano were released by $12 \mathrm{~mm}$ of artificial rain (Table 2). In $90 \%$ of instances the cumulative rainfall at each study site in the Saldanha Bay area during the $5 \mathrm{~d}$ prior to each sample collection was less than $12 \mathrm{~mm}$ (weather reports of the South African Transport Services). However, in only $19 \%$ of cases was the concentration of a nutrient in a low-, mid- or high-shore island rockpool significantly $(\mathrm{P}<0.05)$ correlated with the amount of rain that had fallen during the $5 \mathrm{~d}$ prior to sampling. There was no consistent pattern to these correlations and although one might expect significant correlations between rainfall and the nutrient levels in high-shore pools to be more likely, since nutrients washed from terrestrial guano deposits would reach the high-shore region first, this was not the case. Significant correlations between rainfall and nutrient levels were equally likely in low-shore and in high-shore pools. In no instance was the level of a nutrient in a rockpool at a mainland site correlated with rainfall.

Analyses of nutrient levels recorded at island and mainstream stations across the mouth of Saldanha Bay (Fig. 2) are presented in Fig. 6 (with $\mathrm{NO}_{2}-\mathrm{N}, \mathrm{NO}_{3}-\mathrm{N}$ and $\mathrm{NH}_{4}-\mathrm{N}$ levels combined and expressed as total nitrogen) and Table 3. Mean nutrient levels recorded at island stations generally were higher than those recorded at mainstream stations (77\% of instances), but this relation was seldom significant (Table 3 ). It is noteworthy that the July samples, which did not show the expected trend, were collected during a period when the forces of wind and swell were operating in different directions, which would lead to extensive mixing of the water column (Table 3 ).

\section{DISCUSSION}

The presence of extensive and persistent mats of foliose intertidal algae at offshore islands has been attributed to predation pressure on herbivores (Hockey \& Branch 1984). Intertidal avian predators, particularly oystercatchers, are known to modify the structure of intertidal invertebrate communities by selecting prey of certain species, sizes or morphs (Giesel 1970, Hartwick 1981, Frank 1982, Hockey \& Branch 1983, 1984). On the rocky shores of seabird breeding islands in Saldanha Bay the relatively low densities of Patella granularis (Fig. 3) are evidence for the predatory 


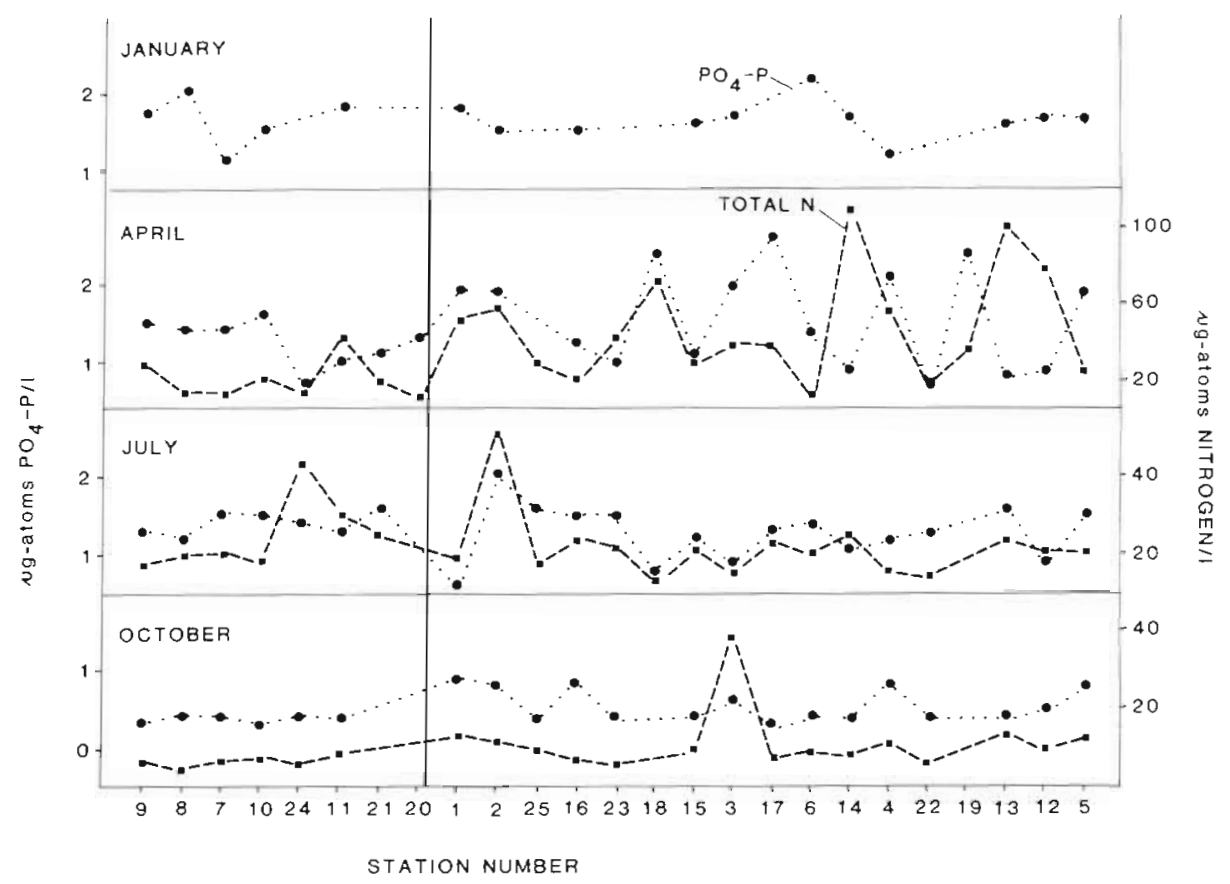

Fig. 6. Concentrations of $\mathrm{PO}_{4}-\mathrm{P}$ and nitrogen (in the form of $\mathrm{NO}_{2}$ $\mathrm{N}, \mathrm{NO}_{3}-\mathrm{N}$ and $\mathrm{NH}_{4}-\mathrm{N}$ ) at sample stations across Saldanha Bay and in a grid around Malgas Island. Stations are arranged in order of decreasing distance from a seabird island shore, with mainstream stations on the left of the vertical line, and island stations on the right

activities of the large numbers of African black oystercatchers (between 25 and 78 birds $\mathrm{km}^{-1}$ island coast; Hockey 1983). The annual removal by oystercatchers of $P$. granularis from the shores of Jutten Island is estimated to be 2.8 million individuals (Hockey \& Branch 1984, Hockey \& Underhill 1984). On mainland rocky shores, where oystercatcher density seldom exceeds 5 birds $\mathrm{km}^{-1}$ coast (Hockey 1983), limpet densities are markedly higher, and algal sporelings are grazed before they become foliose. Thus it is likely that the considerable differences in community structure between island and mainland shores are related, in part, to the activity of oystercatchers.
However, not only is the algal cover significantly higher on island shores than on mainland shores, but also the production rate of intertidal algae on islands is significantly faster. Mats of foliose algae do form on mainland shores when herbivores are excluded, but the production rate is slow in comparison with rates on island shores. Seabird guano has long been recognized as a powerful fertilizer, comprising some $14 \%$ (dry weight) soluble organic compounds, and $3 \%$ soluble mineral salts such as salts of $\mathrm{Mg}, \mathrm{K}, \mathrm{Ca}$ and $\mathrm{Na}$ (Galkina 1974). The composition of seabird guano is comparable between species (Burger et al. 1978, Bédard et al. 1980, Fugler 1985), the dominant soluble organic

Table 3. Results of Kruskal-Wallis statistical tests on mean nutrient levels recorded at island and mainstream stations across the mouth of Saldanha Bay during 1983, and weather conditions prevailing at the time of samplang. $x^{\prime}$ indicates whether island (I) or mainstream (M) stations have the higher mean

\begin{tabular}{|c|c|c|c|c|c|c|c|c|c|c|c|}
\hline Month & Nutrient & $\mathrm{n}_{\mathrm{i}}$ & $n_{M}$ & Statistic & $P$ & I & M & $\begin{array}{l}\text { Wind } \\
\text { speed } \\
\text { (knots) }\end{array}$ & $\begin{array}{l}\text { Wind } \\
\text { direction }\end{array}$ & $\begin{array}{c}\text { Wave } \\
\text { height } \\
\text { (m) }\end{array}$ & $\begin{array}{l}\text { Wave } \\
\text { direction }\end{array}$ \\
\hline Jan & $\mathrm{PO}_{4}^{-} \mathrm{P}$ & 11 & 5 & 0.03 & & & $\mathrm{x}$ & 6.0 & $201^{\circ}$ (SSW) & 2.0 & $201^{\circ}(\mathrm{SSW})$ \\
\hline \multirow[t]{4}{*}{ Apr } & $\mathrm{NO}_{2}-\mathrm{N}$ & 17 & 8 & 4.50 & $<0.05$ & $\mathrm{x}$ & & 1.2 & $246^{\circ}$ (Sib) & 0.3 & $200^{\circ}$ (SSW) \\
\hline & $\mathrm{NO}_{3}-\mathrm{N}$ & 17 & 8 & 9.53 & $<0.005$ & $x$ & & & & & \\
\hline & $\mathrm{NH}_{4}-\mathrm{N}$ & 17 & 8 & 0.82 & & $x$ & & & & & \\
\hline & $\mathrm{PO}_{4}-\mathrm{P}$ & 17 & 8 & 1.30 & & $\mathrm{x}$ & & & & & \\
\hline \multirow[t]{4}{*}{ Jul } & $\mathrm{NO}_{2}-\mathrm{N}$ & 16 & 7 & 0.07 & & $\mathrm{x}$ & & 13.4 & $350:$ (NNW) & 2.5 & $252^{\circ}$ (WSW) \\
\hline & $\mathrm{NO}_{3}-\mathrm{N}$ & 16 & 7 & 1.70 & & & $x$ & & & & \\
\hline & $\mathrm{NH}_{4}-\mathrm{N}$ & 16 & 7 & 0.07 & & $x$ & & & & & \\
\hline & $\mathrm{PO}_{4}-\mathrm{P}$ & 16 & 7 & 0.71 & & & $x$ & & & & \\
\hline \multirow[t]{4}{*}{ Oct } & $\mathrm{NO}_{2}-\mathrm{N}$ & 15 & 6 & 0.12 & & $x$ & & 17.5 & $194^{\circ}(\mathrm{SSW})$ & 3.0 & $232^{\circ}(\mathrm{SW})$ \\
\hline & $\mathrm{NO}_{3}-\mathrm{N}$ & 15 & 6 & 8.30 & $<0.005$ & $x$ & & & & & \\
\hline & $\mathrm{NH}_{4}-\mathrm{N}$ & 15 & 6 & 0.01 & & $x$ & & & & & \\
\hline & $\mathrm{PO}_{4}-\mathrm{P}$ & 15 & 6 & 4.83 & $<0.05$ & $x$ & & & & & \\
\hline
\end{tabular}


compound being uric acid which is rapidly converted to ammonia by the action of aerobic and anaerobic microbes (Lindeboom 1984). Although some of the ammonia subsequently volatilizes from the deposit, much is converted into nitrite and nitrate by nitrifying bacteria. Solutions of cap and fresh seabird guano from the islands in Saldanha Bay contain large amounts of inorganic nutrients in forms available to algae.

The availability of nitrogen and phosphorus are particularly important for marine primary production (de Boer 1982). Marine algae absorb nitrogen in inorganic form (as nitrite, nitrate and ammonium) as well as in organic form (as proteins and amino acids). Ammonium and nitrate are most readily absorbed (de Boer 1982) and the enrichment of growth media with nitrogen in these 2 forms, as well as with phosphorus in the form of phosphate, enhances the growth rates of benthic and intertidal algae in the laboratory (Waite \& Mitchell 1972, Prince 1974, Steffensen 1976, Topinka \& Robbins 1976).

In Saldanha Bay the intertidal and nearshore waters around seabird breeding islands are enriched with nutrients from seabird guano. Shannon \& Stander (1977), in their assessment of the chemical characteristics of the waters of Saldanha Bay, report mean $\mathrm{PO}_{4}-\mathrm{P}$ and $\mathrm{NO}_{3}-\mathrm{N}$ levels, taken over a period of $18 \mathrm{mo}$ at 18 sample stations, of $1.4 \pm 1.0 \mu \mathrm{g}$-at $l^{-1}(\mathrm{n}=191)$ and 5.6 $\pm 5.1 \mu \mathrm{g}$-at $\mathrm{l}^{-1}(\mathrm{n}=190)$ respectively. The low-shore rockpools at Malgas, Jutten and Marcus Islands contain mean concentrations of these nutrients which are almost double the mean background levels: viz. $2.2 \pm$ $0.8 \mu \mathrm{g}$-at $\mathrm{PO}_{4}-\mathrm{Pl}^{-1}(\mathrm{n}=37)$ and $10.3 \pm 5.5 \mu \mathrm{g}$-at $\mathrm{NO}_{3}-$ $N 1^{-1}(n=39)$. Although a sampling frequency of once a month is not sufficient to characterize the nutrient field at each study site (and is not sufficient to indicate a causal relation between enhanced algal growth and elevated levels of any one particular nutrient), the elevated levels of selected nutrients in the waters around the seabird breeding islands are indicative of generally elevated levels of nutrients which are potentially available to enhance intertidal algal growth. The means of entry of guano into the intertidal and nearshore waters are probably multiple. Some guano is deposited directly into the sea by birds which fly over the nearshore, or swim close to the islands, but this is doubtless negligible in comparison with the amount of time the birds spend roosting on the island (at least $50 \%$ for all seabird species considered, and significantly more when the birds are tending chicks). It is likely that rain is not the overriding mechanism by which guano is transported from the land to the sea, particularly in the case of cap guano which is highly porous. Guano is probably transported mainly by waves, particularly during stormy conditions, and dry guano may also be transported by wind.
Golovkin et al. (1976) report a zone of nutrient enrichment around seabird colonies in the Barents Sea, the radius of which is more than $6 \mathrm{~km}$. In Saldanha Bay the movement of guano run-off from the shores of seabird islands is dependent on the directions of the major tidal currents in the Bay. Analysis of surface current flow patterns in Saldanha Bay (Huizinga 1982) has shown there to be transport of surface waters between Malgas Island and North Bay under the influence of normal ebbing and flowing tidal movement, and under the influence of the prevailing SSW wind. Consequently North Bay falls within the zone of nutrient enrichment from Malgas Island and has nutrientrich intertidal waters and enhanced intertidal algal growth. Bomgat lies in a sheltered region on the west side of the harbour breakwater, and the transport of surface waters to and from the site is negligible except under abnormal, storm conditions. Nutrient-rich waters from the shores of Marcus Island would be unlikely ever to reach Bomgat.

The development of extensive algal cover on the shores of North Bay is assumed to be related to the enriched nutrient status of waters washing the intertidal zone, and the resultant enhanced algal growth. However, densities of oystercatchers on the stretch of coast including both the North Bay and Bomgat sites range between 2 and 16 birds $\mathrm{km}^{-1}$ (Hockey 1983), and consequently the effects of removal of limpets by predators cannot be excluded. On Ichaboe Island, where approximately 30000 Cape gannets (Crawford et al. 1983) and 90000 Cape cormorants (Cooper et al. 1982) breed, the mean density of oystercatchers is $1 \mathrm{~km}^{-1}$ of coast (Rand 1963, Hockey 1983), the shorebirds being excluded by densely-packed seabirds. Here limpet predation by oystercatchers is negligible and, although the island was visited only once, algal cover on the shore was comparable with that on nutrient-enriched shores in Saldanha Bay (Fig. 3). Malgas and Jutten Islands clearly have exceptionally extensive algal cover on their shores. Jutten Island supports the highest density of oystercatchers of any of the islands considered ( 74 to 78 birds $\mathrm{km}^{-1}$ of coast; Hockey 1983), and Malgas Island, although presently having the lowest oystercatcher density of the 3 islands (Hockey 1983), has an unexpectedly low density of limpets (Fig. 3). In both these cases the formation of permanent algal beds is likely to be facilitated both by the enhanced intertidal nutrient levels and by the removal of herbivorous limpets by oystercatchers.

Intertidal community structure on the seabird breeding islands in Saldanha Bay is determined by a complex interaction between physical constraints and chemical and biological influences. The concept that predatory shorebirds may modify the population structures of primary consumers, and hence of primary 
producers, is not new. However, the role of coloniallynesting seabirds in determining community structure in the intertidal zone, where seabirds are not involved in the food webs, let alone being dominant or keystone species, has far-reaching implications for the further study of intertidal community dynamics.

Acknowledgements. The Director of the Sea Fisheries Research Institute is thanked for the Institute's help in analysing water samples and for allowing access and providing transport to islands under his control. We acknowledge financial support from the South African National Committee for Oceanographic Research (SANCOR) and thank G.W. McDonald who conducted the artificial rain experiments.

\section{LITERATURE CITED}

Bédard, J., Therriault, J. C., Bérubé, J. (1980). Assessment of the importance of nutrient recycling by seabirds in the St. Lawrence Estuary. Can. J. Fish. Aquat. Sci. 37: 583-588

Bosman, A. L., du Toit, J., Hockey, P. A. R., Branch, G. M. (in press). A field experiment demonstrating the influence of seabird guano on intertidal primary production. Estuar. coast. Shelf Sci.

Burger, A. E., Lindeboom, H. J., Williams, A. J. (1978). The mineral and energy contributions of guano of selected species of birds to the Marion Island terrestrial ecosystem. S. Afr. J. antarct. Res. 8: 59-70

Castilla, J. C. (1981). Perspectivas de investigación en estructura y dinámica de comunidades intermareales rocosas de Chile central. II. De predadores de alto nivel trófico Medio Ambiente 5: 190-215

Connell, J. H. (1961). Effects of competition, predation by Thais lapillus, and other factors on natural populations of the barnacle Balanus balanoides. Ecol. Monogr. 31: $61-104$

Connell, J. H. (1972). Community interactions on marine rocky intertidal shores. Ann. Rev. Ecol. Syst. 3: 169-192

Cooper, J., Brooke, R. K., Shelton, P. A., Crawford, R. J. M. (1982). Distribution, population size and conservation of the Cape cormorant Phalacrocorax capensis. Fish. Bull. S. Afr. 16: 121-143

Crawford, R. J. M., Shelton, P. A., Cooper, J., Brooke, R. K. (1983). Distribution, population size and conservation of the Cape gannet Morus capensis. S. Afr. J. mar. Sci. 1: 153-174

de Boer, J. A. (1982). Nutrients. In: Lobban, C. S., Wynne, M. J. (ed.) The biology of seaweeds. Blackwell, Oxford, p. $356-365$

Edwards, D. C., Conover, D. O., Sutter, F. (1982). Mobile predators and the structure of marine intertidal communities. Ecology 63: 1175-1180

Estes, J. A., Smith, N. S., Palmisano, J. F. (1978). Sea otter predation and community organization in the western Aleutian islands, Alaska. Ecology 59: 822-833

Frank, P. W. (1982). Effects of winter feeding on limpets by black oystercatchers Haematopus bachmani. Ecology 63: $1352-1362$

Fugler, S. R. (1985). Chemical composition of guano of burrowing petrel chicks (Procellariidae) at Marion Island. In: Siegfried, W. R., Condy, P. R., Laws, R. M. (ed.) Antarctic nutrient cycles and food webs. Springer-Verlag, Berlin, p. $169-172$
Galkina, V N. (1974). Chemical composition of soluble substances of excreta of fish-eating sea birds. Ekologiya 5: 23-28

Ganning, B., Wulff, F. (1969). The effects of bird droppings on chemical and biological dynamics in brackish water rockpools. Oikos 20: $274-286$

Giesel, J. T. (1970). On the maintenance of a shell pattern and behavior polymorphism in Acmaea digitalis, a limpet. Evolution 24: 98-119

Gillham, M. E. (1977). Vegetation of sea and shore bird colonies on Aldabra Atoll. Atoll Res. Bull. 200: 1-19

Golovkin, A. N. (1967). The effect of colonial seabirds on the development of phytoplankton. Oceanology 7: 521-529

Golovkin, A. N., Garkavaya, G. P. (1975). Fertilization of waters off the Murmansk coast by bird excreta near various types of colonies. Sov. J. mar. Biol. 1 (5): 345-351

Golovkin, A. N., Shirokolobov, V. N., Garkavaya, G. P. (1976). Peculiarities of distribution of biogenic elements near bird bazaars in the north of Novaya Zemlya. In: Peculiarities of biological productivity of waters near bird's bazaars in the north of Novaya Zemlya. National Science Foundation, Washington, D. C., United States Department of Commerce, Publication PB-267, 499-T, p. 47-65

Hansen, J. E. (1981). Marine plants. In: Le Boeuf, B. J., Kaza, S. (ed.) The natural history of Año Nuevo. Boxwood Press, Pacific Grove, California, p. 183-204

Hartwick, E. B. (1981). Size gradients and shell polymorphism in limpets with consideration of the role of predation. Veliger 23: 254-264

Hockey, P. A. R. (1982). Adaptiveness of nest site selection and egg coloration in the African black oystercatcher Haematopus moquini. Behav. Ecol. Sociobiol. 11: 117-123

Hockey, P. A. R. (1983). The distribution, population size, movements and conservation of the African black oystercatcher Haematopus moquini. Biol. Conserv. 25: 233-262

Hockey, P. A. R., Branch, G. M. (1983). Do oystercatchers influence limpet shell shape? Veliger 26: 139-141

Hockey, P. A. R., Branch, G. M. (1984). Oystercatchers and limpets: impact and implications. A preliminary assessment. Ardea 72: 199-206

Hockey, P. A. R., Underhill, L. G. (1984). Diet of the African black oystercatcher Haematopus moquini on rocky shores: spatial, temporal and sex-related variation. S. Afr. J. Zool. 19: $1-11$

Huizinga, P. (1982). Time series of tidal circulation and velocities in Saldanha Bay. CSIR report T/SEA 8201, Stellenbosch, South Africa

Jeffrey, S. W., Humphrey, G. F. (1975). New spectrophotometric equations for determining chlorophylls $a, b, c_{1}$, and $c_{2}$ in higher plants, algae and natural phytoplankton. Biochem. Physiol. Pflanzen. 167: 191-194

Lewis, J. R. (1964). The ecology of rocky shores, English Universities Press Ltd., London

Lindeboom, H. J. (1984). The nitrogen pathway in a penguin rookery, Ecology 65: 269-277

McQuaid, C. D. (1981). The establishment and maintenance of vertical size gradients in populations of Littorina africana knysnaensis (Philippi) on an exposed rocky shore. J. exp. mar. Biol. Ecol. 54: 77-89

Menge, B. A. (1976). Organization of the New England rocky intertidal community: role of predation, competition and environmental heterogeneity. Ecol. Monogr. 46: 355-393

Mercurio, K. S., Palmer, A. R., Lowell, R. B. (1985). Predatormediated microhabitat partitioning by two species of visually cryptic, intertidal limpets. Ecology 66: 1417-1425

Paine, R. T (1974). Intertidal community structure. Experimental studies on the relationship between a dominant 
competitor and its principal predator. Oecologia (Berl.) 15: 93-120

Prince, J. S. (1974). Nutrient assimilation and growth of some seaweeds in mixtures of seawater and secondary sewage treatment effluents. Aquaculture 4: 69-79

Rand, R. W. (1963). The biology of guano-producing seabirds. 5; composition of colonies on the South West African islands. Div. Sea Fish. Investl Rep. 46, Republic of South Africa

Shannon, L. V., Stander, G. H. (1977). Physical and chemical characteristics of water in Saldanha Bay and Langebaan Lagoon. Trans. R. Soc. S. Afr. 42: 441-459

Shelton, P. A., Crawford, R. J. M., Cooper, J., Brooke, R. K. (1984). Distribution, population size and conservation of the jackass penguin Spheniscus demersus. S. Afr. J. mar. Sci. 2: $217-257$

Smith, V. R. (1978). A qualitative description of energy flow and nutrient cycling in the Marion Island terrestrial ecosystem. Polar Rec. 18: 361-370

Sokal, R. R., Rohlf, F. J. (1981). Biometry, 2nd edn. W. H. Freeman \& Co., San Francisco

Speigt, W. L. (1940). The South African guano islands. Fertilizer, Feeding Stuffs and Farm Supplies J. 25: 242-245
Steffensen, D. A. (1976). The effect of nutrient enrichment and temperature on the growth in culture of Ulva lactuca $\mathrm{L}$. Aquat. Bot. 2: 337-351

Stephenson, T A., Stephenson, A. (1972). Lite between tidemarks on rocky shores, W. H. Freeman \& Co., San Francisco

Strickland, J. D. H., Parsons, T. R. (1972). A practical handbook of seawater analysis. Bull. Fish. Res. Bd Can. 167: 193-196

Topinka, J. A., Robbins, J. V. (1976). Effects of nitrate and ammonium enrichment on growth and nitrogen physiology in Fucus spiralis. Limnol. Oceanogr. 21: 659-664

Voelcker, A. (1877). VII Annual report of the consulting chemist. J. R. Agric. Soc., Series 2 (13): 188-200

Waite, T., Mitchell, R. (1972). The effect of nutrient fertilization on the benthic alga Ulva lactuca. Botanica mar. 15: 151-156

Watson, A. C. (1930). The guano islands of southwestern Africa. Geographical Rev. 20: 631-641

Zelickman, E. A., Golovkin, A. N. (1972). Composition, structure and productivity of neritic plankton communities near the bird colonies of the northern shores of Novaya Zemlya. Mar. Biol. 17: 265-274

This article was presented by Professor J. G. Field; it was accepted for printing on June 19, 1986 